$$
\begin{aligned}
& \text { UCLA } 12 \cdot 873 \\
& \text { Cont -740801-. } 4
\end{aligned}
$$

UNIVERSITY OF CALIFORNIA, LOS ANGELES

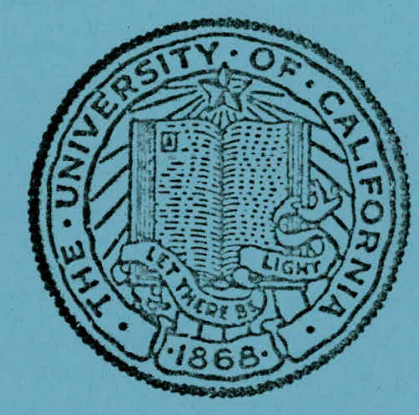

LABORATORY OF NUCLEAR MEDICINE AND RADIATION BIOLOGY CONTRACT NO. AT (04-1) GEN-12

MASTER

DISTRIBUTDN OF THIS DOCUMENT IS UHLIMITE 


\section{DISCLAIMER}

This report was prepared as an account of work sponsored by an agency of the United States Government. Neither the United States Government nor any agency Thereof, nor any of their employees, makes any warranty, express or implied, or assumes any legal liability or responsibility for the accuracy, completeness, or usefulness of any information, apparatus, product, or process disclosed, or represents that its use would not infringe privately owned rights. Reference herein to any specific commercial product, process, or service by trade name, trademark, manufacturer, or otherwise does not necessarily constitute or imply its endorsement, recommendation, or favoring by the United States Government or any agency thereof. The views and opinions of authors expressed herein do not necessarily state or reflect those of the United States Government or any agency thereof. 


\section{DISCLAIMER}

Portions of this document may be illegible in electronic image products. Images are produced from the best available original document. 


\title{
IRON ABSORPTION FROM DIFFERENT SOURCES \\ IN SOIL BY TWO DIFFERENT SOYBEAN VARIETIES \\ (IRON EFFICIENT AND IRON INEFFICIENT)
}

\author{
A. Wallace and R. T. Mueller
}

Soil Science and Agricultural Engineering, Riverside

Laboratory of Nuclear Medicine and Radiation Biology, Los Angeles

University of California

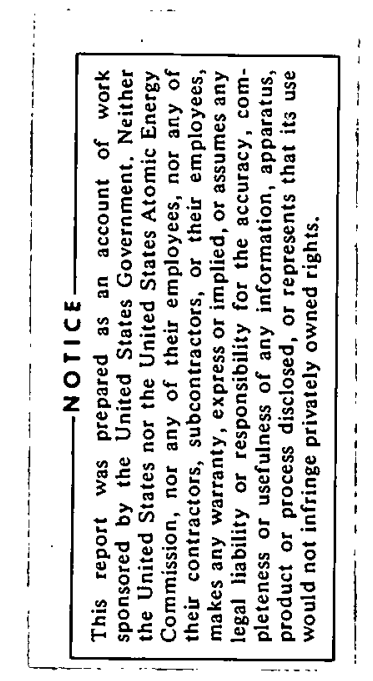

\begin{abstract}
Two soybean varieties (Glycine $\max$ [L.] Merr. Bragg) were grown in a glasshouse with and without a chelating agent in calcareous Hacienda loam soil which had been equilibrated prior to the test with $0,1,2.5$, $5,10,25$, or $50 \mathrm{ppm} \mathrm{Fe}$ from $\mathrm{FeSO}_{4}$ each labeled with ${ }^{59} \mathrm{Fe}$. $\mathrm{Fe}$, ${ }^{59} \mathrm{Fe}$, and specific activities of $\mathrm{Fe}(\mathrm{cpm} / \mu \mathrm{g} \mathrm{Fe})$ were all higher for the Hawkeye than for the PI54619-5-1 soybean. Only with the chelating agent were substantial quantities of $\mathrm{Fe}$ from $\mathrm{FeSO}_{4}$ in the plants. In another test the two soybean varieties were grown in a glasshouse in noncalcareous Yolo loam soil which had been equilibrated with essentially carrier-free ${ }^{59} \mathrm{Fe}$. The specific activity of $\mathrm{Fe}$ was again higher in Hawkeye than in PI54619-5-1. The amount of Fe extracted from the soil by different extracting agents after cropping was not always related to the specific activity of the extract. Specific activities of Fe in the soybeans grown without the chelating agent were nearly like that of the $1 / 10 \mathrm{~N}$
\end{abstract}

This study was supported in part by AEC Contracts (04-3)-34, Proj. \#51, and AT (04-1) Gen 12 between the USAEC and the University of California. 
$\mathrm{HCl}$ extract, and those in the soybeans grown with the chelating agent were nearly like that of the DTPA (diethylene triamine pentaacetic acid) (chelating agent) extract. A reducing agent extracted as much Fe as did the chelating agent, but the specific activity of the extracted $\mathrm{Fe}$ was much lower with the reducing agent.

\section{Introduction}

Iron-efficient plants, like Hawkeye soybeans, absorb more Fe than Feinefficient plants, like PI54619-5-1 soybeans, from both soil and from synthetic chelating agent sources $(1,2)$. The addition of carrier-free ${ }^{59} \mathrm{Fe}$ to calcareous soil in which the $\mathrm{Fe}$-efficient rough lemon and $\mathrm{Fe}$-inefficient trifoliate orange were grown resulted in greater contents of the ${ }^{59} \mathrm{Fe}$ in the former than in the latter even more so than the differences in total $\mathrm{Fe}(6,7)$. There was a great difference even in the presence of synthetic chelating agents. A possible conclusion from the previous studies was that there are different sources of $\mathrm{Fe}$ in the soil and these are differentially available to different species or varieties $(3,4)$. The addition of carrier-free ${ }^{59} \mathrm{Fe}$ to soil does not label all or even much of the $\mathrm{Fe}$ which is available to plants. Chelating agents themselves may cause a separation of soil $\mathrm{Fe}$ into more than one available source. This study was directed at determining if ${ }^{59} \mathrm{Fe}$ and EDDHA (ethylenediamine (di[o-hydroxyphenylacetic acid]) would help ascertain if there is more than one major source of $\mathrm{Fe}$ in soil to/plants and how efficient and inefficient plants differ in their ability to absorb any different sources of $\mathrm{Fe}$ that may exist in soil.

\section{Materials and Methods}

Calcareous Hacienda loam soil (7) was equilibrated with ${ }^{59} \mathrm{Fe}\left(10^{6} \mathrm{cpm} / 500 \mathrm{~g}\right)$ containing sufficient $\mathrm{FeSO}_{4}$ to give either $0,1,2.5,5,10,25$, or $50 \mathrm{ppm} \mathrm{Fe}$ on the dry weight basis in the soil. Each soil received the same amount of ${ }^{59} \mathrm{Fe}$, but 
differing amounts of total Fe. PI54619-5-1 Glycine max (L.) Merr. Bragg) soybeans or Hawkeye soybean seedlings were planted into the soil in 500-g quantities with eight replicates. EDDHA (sodium salt) without Fe was supplied to half the pots and at a rate equivalent to $2.5 \mathrm{ppm} F$ per dry weight of soil if $\mathrm{Fe}$ had been added. The plants were grown in a glasshouse for 12 days. At this time leaves and stems were separated, washed in $0.1 \mathrm{~N} \mathrm{HCl}$ and in distilled-deionized water, then dried, weighed, and prepared for analysis by emission spectrography (8). ${ }^{59} \mathrm{Fe}$ was counted in the samples with a scintillation-well counter.

High specific activity ${ }^{59} \mathrm{Fe}$ (about $40 \mu \mathrm{c} / 600 \mathrm{~g}$ soil) was uniformly mixed (sprayed in solution on thinly spread-out soil which was later thoroughly mixed) and equilibrated for 3 weeks with noncalcareous Yolo loam soil and Hawkeye and PI54619-5-1 soybeans were grown 12 days as explained above. Half of the plants received the chelating agent EDDHA at a rate equivalent to $5 \mathrm{ppm}$ Fe per dry weight of soil, but no Fe was applied (1:1 chelate assumed). All plants received $100 \mathrm{ppm} \mathrm{N}$ per dry weight of soil as $\mathrm{NH}_{4} \mathrm{NO}_{3}$ at the start of the test. The plants were prepared as above. After the plants were removed from the soil, extracts were made of $10 \mathrm{~g}$ quantities of it with $20 \mathrm{ml}$ of DTPA (diethylene triamine pentaacetic acid) (5), $1 / 10 \underline{\mathrm{M} \mathrm{HCl}}, 1 \underline{\mathrm{M} \mathrm{HCl}}$, and $10^{-3} \underline{\mathrm{M}}$ hydroquinone. The latter is a reducing agent and its use was predicated on the observation that ability of efficient species to accumulate $\mathrm{Fe}$ is directly related to the reducing capacity of the root (2). Iron in these extracts was determined colorimetrically with o-phenanthroline. All results for ${ }^{59} \mathrm{Fe}$ were calculated to the date of starting of the experiment to correct for differences due to half-life of ${ }^{59} \mathrm{Fe}$.

\section{Results and Discussion}

All the PI54619-5-1 plants in the Hacienda loam were yellow from Fe chlorosis. This occurred even though leaves of those with EDDHA contained generally more 
Fe than Hawkeye soybeans without EDDHA (Table 1). The latter were green as were all Hawkeye plants. Application of labeled Fe to the soil resulted in relatively little uptake of it by either plant variety unless EDDHA was also added. More of the labeled Fe was taken up by Hawkeye plants than PI54619-5-1 plants with or without the chelating agent (Table 1).

An important point is that the ${ }^{59} \mathrm{Fe}$-labeled Fe was essentially not the Fe available to plants without the chelating agent. The chelating agent made the labeled Fe more available than it otherwise was. The addition of $\mathrm{FeSO}_{4}$ at 50 ppm per dry weight of soil had little effect on the uptake of Fe without chelating agent; some of it was taken up, but it did not seem to add to the total uptake. With the chelating agent, increasing quantities of the added ${ }^{59} \mathrm{Fe}$ from $\mathrm{FeSO}_{4}$ were found in the plants. As this quantity increased, there was a decreased amount of $\mathrm{Fe}$ in the plants from other sources.

It is not possible to determine with the chelate treatments if all the Fe available to the plants were chelated or if some were available without being chelated. The near constant specific activity of $\mathrm{Fe}$ in the plants with chelates would indicate that the chelating agents chelated close to an equal amount of Fe in all treatments and that the Fe chelated from the added $\mathrm{FeSO}_{4}$ source largely displaced other Fe which would be chelated. Two sources of Fe at least then were being utilized, but both would be subject to chelation before absorption by the plants.

Further confirmation of the hypothesis that different sources of Fe are available to plants was obtained in the second experiment. The plants grown in noncalcareous Yolo loam (Table 2) contained more Fe than those in calcareous Hacienda loam (Table 1). The specific activity of ${ }^{59}$ Fe in plants was slightly higher for the Hawkeye than for the PI54619-5-1 variety with or without the chelating agent applied to the soil (with the calcareous soil (Table 1) it was much higher for Hawkeye than for PI54619-5-1 soybeans). The chelating agent 
approximately doubled the specific activities of ${ }^{59} \mathrm{Fe}$ in the leaves without changing the total $\mathrm{Fe}$ content of leaves. This indicates that the chelating agent was extracting and making available a source of $\mathrm{Fe}$ that otherwise was not very available to the plants. The data from the extracting agents also indicated that the agents extracted somewhat different sources of $\mathrm{Fe}$ from the soil (Table 3). For example, the reducing agent extracted more $\mathrm{Fe}$ than did the chelating agent, but the specific activity of the ${ }^{59} \mathrm{Fe}$ with the reducing agent was only one-eighth that with the

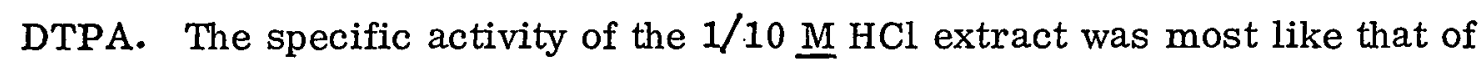
both soybean varieties grown while that with the DTPA extract was most like the soybeans grown with the EDDHA. These results circumstantially provide evidence that different sources of $\mathrm{Fe}$ which are differentially available to different plants do exist in soil. 


\section{References}

1. Brown, J. C. 1961 Iron chlorosis in plants. Advan. in Agron. 13:339-369.

2. Brown, J. C., R. S. Holmes, and L. O. Tiffin 1961 Iron chlorosis in soybeans as related to the genotype of rootstalk: $\amalg$. Chlorosis susceptibility and reductive capacity at the root. Soil Sci. $91: 127-132$.

3. Elgala, A. M. and R. H. Maier 1964 Chemical forms of plants and soil iron as influenced by soil moisture. Plant and Soil 11(2):201-212.

4. Elgala, A. M. and R. H. Maier 1971 Effect of ethylenediamine di (o-hydroxyphenylacetic acid) application to soil columns on the distribution of certain nutrient elements in the water-soluble, acid-soluble and exchangeable forms. Plant and Soil $34(3): 607-617$.

5. Lindsay, W. L. and W. A. Norvell 1969 Development of a DTPA micronutrient soil test. Agron. Absts. Amer. Soc. Agron. Ann. Meet., p. 84.

6. Wallace, A. 1972 Effect of chelating agents and rootstock on specific activity of iron and zinc in orange shoots after ${ }^{59} \mathrm{Fe}$ and ${ }^{65} \mathrm{Zn}$ had been added to soil. Symp. on Use of Isotopes and Rad. in Res. on Soil Plant Relationships Including Forestry. IAEA Symp. Vienna, 531-537.

7. Wallace, A. and R. T. Mueller 1969 Effect of chelating agents on the availability to plants of carrier-free ${ }^{59} \mathrm{Fe}$ and ${ }^{65} \mathrm{Zn}$ added to soils to simulate contamination from fallout. Soil Sci. Soc. Amer. Proc. 33(6):912-914.

8. Wallace, A. and Collaborators 1971 Mineral element analyses of plants by means of an emission spectrograph, In A. Wallace editor and publisher, Regulation of the Micronutrient Status of Plants by Chelating Agents and Other Factors, Los Angeles, Calif. p. 1-4. 
Table 1. Iron and ${ }^{59} \mathrm{Fe}$ contents of leaves of two varieties of soybeans with and without chelating agents.

\begin{tabular}{|c|c|c|c|c|c|c|c|c|c|c|}
\hline \multirow{3}{*}{$\begin{array}{c}\mathrm{Fe} \\
\text { added } \\
\text { to soil } \\
\mathrm{ppm}\end{array}$} & \multicolumn{5}{|c|}{0 EDDHA } & \multicolumn{5}{|c|}{ EDDHA } \\
\hline & $\begin{array}{l}\text { Yield } \\
\text { mg/. } \\
\text { plant }\end{array}$ & $\frac{\mathrm{cpm} \mathrm{Fe}^{59}}{\mu \mathrm{g} \mathrm{Fe}}$ & $\begin{array}{l}\mathrm{Fe} \\
\mathrm{ppm}\end{array}$ & $\begin{array}{l}\mathrm{Fe}^{*} \\
\mathrm{ppm}\end{array}$ & $\begin{array}{c}\mathrm{Fe}-\mathrm{Fe} \\
\mathrm{ppm}\end{array}$ & Yield & $\frac{\mathrm{cpm} \mathrm{Fe}^{59}}{\mu \mathrm{g} \mathrm{Fe}}$ & $\begin{array}{c}\mathrm{Fe} \\
\mathrm{ppm}\end{array}$ & $\begin{array}{c}\mathrm{Fe}^{*} \\
\mathrm{ppm}\end{array}$ & $\begin{array}{c}\mathrm{Fe}-\mathrm{Fe}^{*} \\
\mathrm{ppm}\end{array}$ \\
\hline & \multicolumn{10}{|c|}{ PI54619-5-1 soybeans } \\
\hline 0 & 190 & 0.0 & 52 & 0.00 & 52 & 171 & 62.4 & 61 & 0.00 & 61 \\
\hline 1 & 198 & 0.0 & 56 & 0.00 & 56 & 185 & 70.8 & 73 & 0.73 & 72 \\
\hline 2.5 & 224 & 0.0 & 53 & 0.00 & 53 & 180 & 65.6 & 62 & 1.88 & 60 \\
\hline 5 & 161 & 0.0 & 43 & 0.00 & 43 & 168 & 45.0 & 66 & 2.41 & 64 \\
\hline 10 & 143 & 6.9 & 40 & 0.32 & 40 & 180 & 54.8 & 61 & 6.69 & 54 \\
\hline 25 & 194 & 1.5 & 49 & $0.24:$ & 49 & 202 & 42.0 & 78 & 16.5 & 62 \\
\hline \multirow[t]{2}{*}{50} & 198 & 1.0 & 29 & 0.60 & 29 & 216 & 44.9 & 74 & 29.8 & 44 \\
\hline & \multicolumn{10}{|c|}{ Hawkeye soybeans. } \\
\hline 0 & 262 & 7.8 & 60 & 0.00 & 60. & 247 & 76.9 & 75 & 0.00 & 75 \\
\hline 1 & 283 & 14.5 & 50 & 0.11 & 50 & 230 & 66.1 & 93 & 1.15 & 92 \\
\hline 2.5 & 324 & 8.3 & 59 & 0.25 & 59 & 244 & 70.1 & 81 & 3.01 & 78 \\
\hline 5 & 302 & 11.0 & 50 & 0.44 & 54 & 234 & 52.5 & 67 & 3.30 & 64 \\
\hline 10 & 212 & 9.4 & 53 & 1.07 & 52 & 228 & 80.6 & 71 & 12.4 & 59 \\
\hline 25 & 348 & 2.6 & 43 & 1.70 & 41 & 206 & 50.4 & 82 & 19.4 & 63 \\
\hline 50 & 322 & 3.8 & 63 & 2.79 & 60 & 253 & 48.7 & 78 & 38.3 & 40 \\
\hline LSD . 05 & 63 & 4.0 & 8 & 0.21 & 8 & 63 & 15.2 & 14 & 3.0 & 7 \\
\hline LSD . 01 & 83 & 5.2 & 12 & 0.27 & 12 & 83 & 20.0 & NS & 4.2 & 9. \\
\hline
\end{tabular}

* Fe in plants from added $\mathrm{FeSO}_{4}$ as determined from specific activity relationships. $\mathrm{Fe}-\mathrm{Fe}{ }^{*}$ represents the nonlabeled $\mathrm{Fe}$ in the leaves. All data on dry weight basis. 
Table 2. Fe and specific activity of it in trifoliate leaves of the soybean plants grown in Yolo soil (12 replicates). All data are on dry weight basis.

$\begin{array}{lcc}\begin{array}{c}\text { Soybean } \\ \text { and } \\ \text { treatment }\end{array} & \begin{array}{c}\text { Fe in } \\ \text { trifoliate } \\ \text { leaves }\end{array} & \begin{array}{c}\text { Specific } \\ \text { activity }\end{array} \\ \text { PI54619-5-1 control } & \text { ppm } & \mathrm{cpm}^{59} \mathrm{Fe} / \mu \mathrm{g} \mathrm{Fe} \\ \text { PI54619-5-1 + EDDHA } & 106 & 8.1 \\ \text { Hawkeye control } & 100 & 18.7 \\ \text { Hawkeye + EDDHA } & 118 & 10.6 \\ \text { LSD . 05 } & 118 & 20.5 \\ \text { LSD . 01 } & 8 & 1.1 \\ \end{array}$


Table 3. Fe extracted from the Yolo loam soil by different agents and specific activity of the Fe. (12 replicates) All data are on dry weight basis.

$\begin{array}{lcc}\text { Extractant } & \begin{array}{c}\text { Fe in } \\ \text { extract }\end{array} & \begin{array}{c}\text { Specific } \\ \text { activity } \\ \text { of Fe in } \\ \text { extract }\end{array} \\ & \text { ppm } & \text { cpm }^{59} \mathrm{Fe} / \mu \mathrm{g} \mathrm{Fe} \\ \text { DTPA } & 14.4 & 30.1 \\ 1 / 10 \text { N HCl } & 1.6 & 13.0 \\ 1 \mathrm{~N} . \mathrm{HCl} & 33.0 & 81.7 \\ 10^{-3} \text { M hydroquinone } & 18.8 & 3.6 \\ \text { LSD . 05 } & & 4.1 \\ \text { LSD . 01 } & 2.2 & 5.3\end{array}$


•

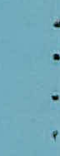

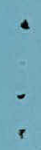
.

• 